\title{
UMA HIPÓTESE SOBRE UMA FALSA DICOTOMIA ENTRE LÓGICA E FILOSOFIA
}

\author{
Evandro Luís Gomes ${ }^{1}$
}

\begin{abstract}
RESUMO
A fim de elucidar uma falsa dicotomia entre a filosofia e a lógica, enunciamos uma hipótese que credita a gênese de tal tensão à índole das relações (efetivas ou pretendidas) entre lógica e filosofia. Da relutância ao desabono, duas posturas teóricas parecem explicar o presente cenário, i.e., se um determinado autor ou escola filosófica considera ou não a lógica parte constitutiva da filosofia ou se seria dessa apenas mero instrumento. Procuramos explicar as razões dessa indiferença e reiteramos, por fim, como a lógica é indispensável a qualquer boa filosofia.
\end{abstract}

Palavras-chave: Lógica. Dialética. Órganon. Filosofia. Ensino de Lógica. Filosofia Moderna.

\begin{abstract}
In order to elucidate the false dichotomy between philosophy and logic, I analyze the hypothesis that credits the genesis of such concern to the nature of the relations (effective or intended) between logic and philosophy. From reluctance to despondency, two theoretical positions seem to explain the present scenario, i.e., as whether a particular author or philosophical school considers or not logic a constitutive part of philosophy, or whether it is just its mere instrument. Since Brazilian philosophical scenario expresses a certain reticence and, at times, disregard towards logic, I proceed to explain the reasons for this indifference and so reiterate, finally, how logic is indispensable to any good philosophy.
\end{abstract}

Keywords: Logic. Dialectic. Organon. Philosophy. Logic Teaching. Modern Philosophy.

\footnotetext{
${ }^{1}$ Departamento de Filosofia, Programa de Pós-Graduação em Filosofia, Centro de Ciências Humanas, Letras e Artes, Universidade Estadual de Maringá (PR). Agradecemos aos organizadores do I Colóquio de Lógica da Universidade Federal de Uberlândia, especialmente aos professores Márcio Chaves-Tannus e Marcos Seneda, pelo convite para a conferência que originou o presente ensaio. Agradeço também aos professores Itala M. Loffredo D’Ottaviano, Ricardo Pereira Tassinari e Fábio M. Bertato, pelas frutíferas discussões acerca do tema. E-mail: elgomes@uem.br. ORCID: 0000-0002-7570-6791.
} 


\section{Introdução}

As origens da lógica no pensamento ocidental remontam aos primórdios da filosofia grega. Gestada naquele contexto, foi só aos poucos que a lógica - então designada por diferentes nomes, sendo analítica ${ }^{2}$ e dialética ${ }^{3}$ os mais célebres - foi distinguida e constituída em campo próprio de estudos. ${ }^{4}$

Mesmo considerando as nuances de escola, métodos e teorias, é possível identificar uma constante quanto ao objeto a que visa a lógica através de sua história. Pode-se afirmar, de modo geral, que a lógica se dedica ao estudo dos princípios, leis e regras concernentes à inferência válida ou correta. Seu propósito, explica Bocheński (1966, p. 2, 40), consiste em determinar as condições formais da validade lógica, bem como a construção de seus respectivos modelos, seja no escrutínio da noção de demonstração, seja no exame da noção de dedução formal tal como empregada na análise de argumentos. Assim concebida, assere Bocheński (1951, p. 9, 14, 19; 1966, p. 110), a lógica constituiu-se apenas a partir do legado de Aristóteles, pois foi somente com o Estagirita que ela se tornou disciplina autônoma e seu objeto passou a ser estudado por sua própria sorte.

Se ainda hoje persiste alguma tensão entre lógica e filosofia na percepção de alguns acadêmicos, neste ensaio, analisamos uma hipótese que credita à índole das relações (efetivas ou pretendidas) entre lógica e filosofia a eluci-

\footnotetext{
${ }^{2}$ Tal denominação vincula-se à tradição peripatética. Na verdade, explica Bocheński (1966, p. 57), "Aristóteles no posee ninguna denominación técnica para la Lógica: lo que nosotros

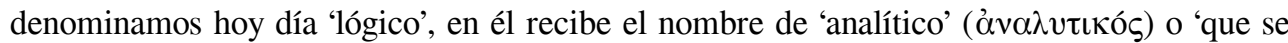

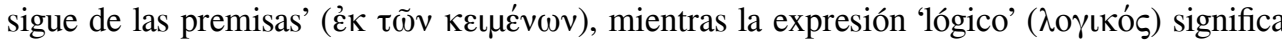
lo mismo que nuestro "probable' o bien 'epistemológico"”.

${ }^{3}$ Essa denominação está associada à tradição megárico-estoica. De fato, argumenta Blanché (2001, p. 93), “a expressão consagrada de 'lógica dos estoicos', que não teremos escrúpulos em empregar, é, com todo o rigor, duplamente inexata. Primeiro, porque o que nós chamamos a sua lógica, os estoicos chamavam-lhe antes dialética, designando neles (sic) a palavra 'lógica', num sentido mais amplo, tudo o que se refere à linguagem, $\lambda$ ó$_{0} \varsigma_{\zeta}$, incluindo a retórica e a gramática". Em segundo lugar, sustenta Blanché (Id., ib.), "por muito reduzidas que sejam as informações que possuímos sobre os megáricos, o que deles sabemos basta para nos certificar que são os verdadeiros fundadores da lógica dita estoica, e seria de toda justiça qualificar de preferência tal lógica de megárico-estoica". Não obstante, perante o fato de que a forma madura da lógica estoica foi alcançada apenas com Crisipo de Soli, a posição de Blanché, que segue a de Bocheński (1966, p. 117), levanta certa controvérsia entre os estudiosos.

${ }^{4}$ É com propriedade que Guthrie (1962, vol. 1, p. xi; nossa tradução) afirma que "muito do que poderia agora ser considerado como filosófico - teoria ética e política, lógica e episte mologia - ou é totalmente ausente nesse período [pré-socrático], ou se apresenta num estágio embrionário".
} 
dação de tal inquietação. Chegamos, assim, ao cerne do que denominamos "falsa dicotomia entre lógica e filosofia", que tem se traduzido, por vezes, em relutância filosófica à lógica tanto em certos momentos da história da filosofia quanto em certos círculos filosóficos do tempo presente..$^{5}$ A fim de compreender as razões dessa tensão epistemológica que, por vezes, se converte em menoscabo, procuramos descrever a hipótese de que a relação entre lógica e filosofia, bem como os papéis esperados e desempenhados pela lógica em diferentes contextos teóricos, está na base dessa atitude. Assim, examinamos duas posturas teóricas, i.e., se um determinado autor ou escola filosófica considera ou não a lógica ( $i$ ) mero instrumento da filosofia ou (ii) seria dela parte constitutiva. ${ }^{6}$

\section{Sobre as relações entre lógica e filosofia}

Enquanto saber racional, parece pacífico que a filosofia não possa prescindir da lógica, pois esta, argumenta Newton da Costa (1980, p. 4), em seus diferentes níveis de análise, formalismo e linguagem, codifica o caráter inferencial da atividade racional e teórica. Não por acaso, já entre os filósofos pré-socráticos encontram-se pistas valiosas que registram o nascimento da lógica entre os gregos. Foi a partir da análise minuciosa do discurso ordinário, da necessidade premente de distinguir as consequências logicamente lícitas das ilícitas, que o desenvolvimento da lógica pôs-se em movimento. Primeiro, como explica Santos (2008, p. 1-30), no contexto da isegoria típica da pólis grega, no qual a lógica emerge do exercício argumentativo político-jurídico, e, paulatinamente, com o incremento do debate filosófico, a lógica dirige-se à argumentação teórica em crescente contraste com a sofística, a fim de caracterizar efetivamente a correlação entre verdade e demonstração. A primeira contribuição notável, nesse sentido, é-nos legada por Parmênides. Os desdo-

\footnotetext{
${ }^{5}$ No que tange aos "círculos filosóficos do tempo", a presente percepção é pessoal, porém retrata vivências acadêmicas análogas de diversos atores da comunidade lógico-filosófica.

${ }^{6}$ Há outros aspectos que pertencem ao problema em tela, como o contraste entre a eficácia teórico-dedutiva e as expectativas epistêmicas cumuladas à lógica, assim como aqueles que se derivam do magistério de lógica em determinados períodos da história e às aspirações de modernidade em confronto com tradições lógico-filosóficas historicamente estabelecidas. Todavia, pretendemos encetar tal discussão, deveras interessante, em outra oportunidade.
} 
bramentos ontológicos e lógico-epistêmicos das teses parmenidianas sobre aquilo que é ( đò óv), as quais configuram proto-enunciados dos princípios de identidade, do terceiro excluído e de não contradição - e acerca das vias do conhecimento -, são, assim, decisivos para toda a filosofia ocidental. ${ }^{7}$

\subsection{A lógica enquanto instrumental para a filosofia}

Apesar de a lógica propriamente formal e de caráter nomológico ter se estabelecido enquanto disciplina somente a partir da contribuição aristotélica, sabe-se que esquemas de inferência e princípios lógicos foram utilizados e enunciados no período pré-aristotélico da história da lógica grega (Bocheński, 1951, p. 14-18). Zenão de Eleia, nesse sentido, desempenha um papel mais importante do que se costuma reconhecer no tocante à história da lógica ocidental.

Embora Zenão frequentemente seja encarado como feroz defensor do monismo ontológico de Parmênides, atualmente essa interpretação é bastante disputada, sendo possível sustentar que ele argumenta indistintamente contra ambos, tanto o pluralismo quanto o monismo. ${ }^{8}$ Desse modo, seu intento parece ser dialetizar as diversas posições filosóficas em debate à época.

A posição de destaque que Zenão ocupa no panorama filosófico helênico deve-se, sobretudo, às conclusões deconcertantes a que chegou por meio de esquemas de inferência apagógicos. ${ }^{9}$ Zenão, pela primeira vez no Ocidente, aponta para a existência da distinção entre forma e conteúdo da argumentação no debate filosófico. Provavelmente essa é a razão de ele ter sido considerado por Aristóteles o fundador da dialética, conforme relata Diógenes Laércio: “Aristóteles diz no Sofista que Empédocles foi o inventor da retórica, e Zenão, da dialética" ${ }^{10}$ Considerado fidedigno, esse relato circunscreve-se a um con-

\footnotetext{
${ }^{7}$ Austin (1986, p. 9). A propósito dessa leitura, alguns estudiosos defendem que a Parmênides, e não a Aristóteles, deveria ser outorgado o título de fundador da lógica; vide Enriques (1948, p. 8-10).

${ }^{8}$ Cf. Barnes (2000, p. 235-236) e Cordero (1994, vol. II, p. 17-21). Barnes o considera mais um autor perspicaz que um devoto defensor das ideias de Parmênides.

${ }^{9}$ São apagógicas as estratégias de demonstração indireta e de caráter refutativo, como o método de redução ao impossível ou absurdo. Para uma discussão mais detalhada dos métodos dialético-apagógicos de Zenão, vide Gomes \& D’Ottaviano (2017, p. 70-75).

${ }^{10}$ Vitae philosophorum VIII, 57. Tradução de M. da G. Kury, cf. Diógenes Laércio (2008, p.

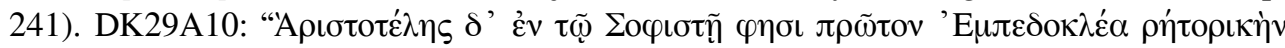


texto específico, em que Aristóteles e os doxógrafos teriam reconhecido semelhanças entre o método de Zenão e o dos filósofos megáricos, tanto exercido por Sócrates quanto exemplificado nos primeiros diálogos de Platão. ${ }^{11}$ Daí a dialética zenoniana constituir-se, segundo Cordero (1994, p. 21; 33), em uma “técnica de discussão", em especial como exercício de inferência, uma espécie de ginástica mental, um método sem qualquer orientação filosófica específica. De acordo com Cordero, o relato de Simplício testemunha essa interpretação: "Parece que Zenón intentaba, a modo de ejercitación (gymnastikós), demonstrar ambas cosas (o sea, lo uno y la multiplicidad). Por eso era llamado 'bilingüe'; y planteaba dificultades acerca de lo uno con estos argumentos” (In Physica 139, 3-6, apud Cordero, 1994, p. 32, 36). Zenão parece, assim, ter sido o primeiro a utilizar-se de esquemas formais de demonstração e a empregá-los deliberadamente na investigação filosófica.

Outra novidade metodológica de Zenão de Eleia é a consideração em separado da forma com relação ao conteúdo da argumentação desenvolvida. E, de acordo com Cordero (1994, p. 20), nisso consiste sua originalidade filosófica, i.e., o emprego puramente formal de esquemas de argumentação em dialética. Precursor dos dissoi logoi de Protágoras, Zenão apresenta uma contribuição à história da filosofia e da lógica que parece ter sido de índole metodológica. Assim, explica Cordero (1994, p. 20-21), o filósofo teria tornado independentes de seus contextos conceituais certos métodos formais, como a redução ao absurdo, a fim de argumentar a favor e contra determinadas hipóteses. Tal acepção "instrumental" da lógica se vislumbra também em Platão. ${ }^{12}$ Embora a dialética seja muito cara ao mestre de Aristóteles, não é no sentido de uma disciplina própria, de índole formal, que ela ali se efetiva. De acordo com Bocheński (1966, p. 45), mesmo tendo Platão levado em conta esquemas de inferência lógicos e nitidamente empregados em toda a sua obra, e ainda

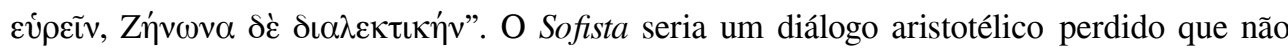
chegou até nós.

${ }^{11}$ Cf. Cordero (1994, p. 20-21); vide também Kirk, Raven \& Schofield (1994, p. 290).

${ }^{12}$ De acordo com Laudan (2000, p. 27-28), provém do relato de comentadores antigos como Simplício, que repercute a opinião de Geminus (primeiro século depois de Cristo), de que Platão estaria, mutatis mutandis, igualmente vinculado à tradição instrumental em ciência, ao ser reconhecido como fundador da tradição grega posterior de "salvar os fenômenos" (apparentias salvare). 
que tenha enunciado pela primeira vez um conceito correto de lógica no $\mathrm{Ti}$ теи (47 B-C), ele nunca estudou a lógica por si mesma.

Embora Zenão pareça ter sido o primeiro a conceber a lógica (dialética) como instrumento do filosofar, essa concepção de lógica foi vinculada a Aristóteles e à sua escola, como consagra a tradição posterior. ${ }^{13}$ Assim sendo, apesar de Aristóteles empregar o termo organon (őp $\gamma \alpha v o v$ ) em diversas passagens (cf. Top. 108b 30; 163b 10), a imposição à lógica de um caráter instrumental, com fundamento em alguns acenos no corpus aristotelicum, deve-se, sobretudo, aos comentadores gregos do Estagirita. ${ }^{14}$

De fato, Aristóteles não teria deixado tão clara sua posição quanto à lógica ser parte da filosofia ou dela mero instrumento. Com efeito, argumenta Bocheński (1966, p. 57, nossa tradução), “a questão de se a lógica é uma parte da filosofia ou seu instrumento (o’ $\rho \gamma \alpha v o v)$ e, por conseguinte, uma arte, não tratou dela Aristóteles em nenhuma parte dos escritos que conservamos". Entretanto, em um das poucas passagens em que aborda o tema abertamente, Aristóteles indica que em toda arte ( $\tau \dot{\varepsilon} \chi v \eta)$ são necessários instrumentos e que esses são de muitas espécies (cf. Pol. 1253b 28). Todavia, em nenhum lugar ele afirma que a lógica é um instrumento da filosofia. Não obstante, encontra-se em Aristóteles a defesa de que a lógica é não apenas uma parte da filosofia, mas uma disciplina preparatória, um pré-requisito ao filosofar:

Quanto a tudo aquilo que alguns (entre os que foram mencionados) tentam estabelecer a respeito da verdade, concernente ao modo pelo qual é preciso aceitá-la, fazem-no devido à falta de formação nos Analíticos; de fato, é preciso chegar já sabendo previamente esses assuntos, mas não buscá-los enquanto se ouve [sc. o presente curso].

\footnotetext{
${ }^{13}$ Com efeito, Andrônico de Rodes, quando resgatou os escritos de Aristóteles, por volta do I século a.C., agrupou os tratados lógicos como hoje conhecemos, porém a denominação "órganon" é ainda posterior; vide Bocheński (1966, p. 52-53) e Blanché (2001, p. 27-28, n. 1, 2 e 3). Kneale \& Kneale (1991, p. 25) explicam que "quando os escritos de Aristóteles foram reunidos pelos seus alunos depois da sua morte em 322 a.C., uma série dos seus tratados sobre o raciocínio foi agrupada e a coleção acabou por se chamar Organon, ou instrumento da ciência. A palavra 'lógica' só adquiriu o seu sentido moderno 500 anos mais tarde quando foi usada por Alexandre de Afrodísias; mas o âmbito da investigação, mais tarde chamada lógica, foi determinado pelo conteúdo do Organon".

${ }^{14}$ De fato, Alexandre de Afrodísia e João Filopono que teriam difundido tal uso; cf. Ferrater Mora $(2000$, t. 3, p. 2170-2171). Tais comentadores, entretanto, não se referiam a todos os tratados indistintamente, conjuntamente considerados, mas apenas ao seu conteúdo, à doutrina lógica ali exposta.
} 
Assim, é evidente que compete ao filósofo, isto é, àquele que estuda como naturalmente se apresenta qualquer essência, investigar também a respeito dos princípios silogísticos. E convém que aquele que mais conhece a respeito de cada gênero seja capaz de enunciar os princípios mais firmes do assunto, de modo que também aquele que conhece a respeito dos entes enquanto são entes é capaz de enunciar os princípios mais firmes de todas as coisas. E este é o filósofo. $(\text { Met. } \Gamma 1005 b)^{15}$

Consequentemente, carece de fundamento a opinião amplamente difundida de que a lógica seria, para os peripatéticos, um mero instrumento, e não parte da filosofia. Essa opinião reforça a leitura de que, para Aristóteles, seria forçada a separação entre lógica e filosofia. Ademais, isso implica, precisamente, que a lógica ali só poderia ser arbitrariamente separada da filosofia. Nesse sentido, explica Correia (2002, p. 11, nossa tradução),

a chamada "lógica de Aristóteles" é uma consequência de uma teoria dialética e ontológica que, se bem possa converter-se desde este mesmo princípio numa disciplina formal, não pode identificar-se somente com ela. Daí que a lógica, para seu fundador, não é nem uma dialética, nem uma ontologia, nem uma lógica formal, senão tudo isso junto, historicamente fundido.

Desse modo, foi a partir da indicação aristotélica do caráter propedêutico da lógica (i.e., da analítica) que se amoldou e repercutiu a opinião dos comentadores antigos, de que a lógica fosse encarada como instrumento da filosofia e das ciências. A tradição lógica e filosófica medieval teria aprofundado a indicação dos comentadores de que a lógica seria instrumento da filosofia. Parece aí haver uma especial influência da revalorização aristotélica ocorrida na Antiguidade tardia e na filosofia escolástica, o que teria levado, inclusive, à pretensão de um purismo aristotélico. Um exemplo dessa concepção encontra-se na Carta-Prefácio da Suma de toda a lógica. Guilherme de Ockham considera a lógica essencial para o desenvolvimento de todas as demais ciências e exemplifica a ideia da lógica como uma arte, mas também como instrumento imprescindível ao empreendimento da atividade racional:

Pois a lógica é a mais útil de todas as artes. Sem ela, nenhuma ciência poderia ser totalmente conhecida. Ela não se esgota pelo uso repetido, segundo a maneira das ferramentas materiais, mas antes admite crescimento contínuo por meio do exercício diligente de qual-

${ }^{15}$ Tradução de Lucas Angioni; cf. Aristóteles (2001, p. 18). 
quer outra ciência. Pois exatamente como um mecânico, a quem falta um completo conhecimento de sua ferramenta, ganha um mais completo [conhecimento] por usá-la, assim alguém que é educado nos firmes princípios da lógica, enquanto meticulosamente devota seu trabalho a outras ciências, adquire ao mesmo tempo uma habilidade maior nessa arte. (Summa totius logicae, Epistola Proemialis, nossa tradução) $)^{16}$

Semelhante elogio à lógica jamais poderia desaboná-la. Ao longo da história da filosofia e no compasso do alvorecer da matematização da lógica, sobretudo no século XIX, muitos estudiosos que não assimilaram essa radical transformação no cerne da disciplina passaram e vê-la como algo estranho ao seu próprio ofício, ao mesmo tempo que se sentiam capazes de desenvolver seus temas e problemas sem recorrer aos métodos da lógica de suas respectivas épocas, em especial, mais recentemente, com sua apresentação simbólica e matematizada. ${ }^{17}$ Eis uma das facetas da falsa dicotomia entre lógica e filosofia. Por outro lado, ao encararem seus próprios interesses teóricos em filosofia como lógico-independentes, muitos estudiosos parecem considerar suficiente a posse de um pequeno arsenal metalógico de índole informal e de natureza lógico-clássica. Métodos tradicionais em história da filosofia, tal como consagrada no Brasil - de índole hermenêutica e estrutural -, fundamentam a análise dos temas e autores a partir de seus conceitos-chave e de maneira interna a seus próprios sistemas de pensamento, como se a arquitetura dos conceitos entrelaçados por esses autores pudesse oferecer-lhes as ferramentas necessárias. Ou seja, existe uma suposição de que a lógica interna ao discurso de um autor basta à correta discussão de um sistema de conceitos. Aqui, a lógica de que falamos desde o princípio é preterida em favor de uma racionalidade localíssima, uma "lógica", sem dúvida, muito peculiar; trata-se, como a entende-

\footnotetext{
16 "Logica enim est omnium artium aptissimum instrumentum, sine qua nulla scientia perfecte sciri potest, quae non more materialium instrumentorum usu crebro consumitur, sed per cuiuslibet alterius scientiae studiosum exercitium continuum recipit incrementum. Sicut enim mecanicus sui instrumenti perfecta carens notitia utendo eodem recipit pleniorem, sic in solidis logicae principiis eruditus dum, aliis scientiis operam impendit sollicite simul istius artis maiorem adquirit peritiam. Unde illud uulgare 'ars logica labilis ars est' in solis sapientiale studium negligentibus locum reputo obtinere."

17 É conhecido o desabono dos métodos da lógica pelos filósofos modernos, seus herdeiros e intérpretes. Embora haja honrosas exceções, como Leibniz e Kant, é pacífico afirmar que a lógica não atendia às aspirações epistemológicas daqueles filósofos que nela procuraram sem, contudo, encontrar -, sobretudo, uma arte da descoberta (ars inveniendi). Cf. Cassirer (1994).
} 
mos, de um aprofundamento antitético da visão de que a lógica, enquanto disciplina historicamente estabelecida e teoricamente fundante, não é nem sequer instrumento da filosofia.

\subsection{A lógica enquanto parte intrínseca da filosofia}

Um exemplo emblemático do vínculo da lógica à filosofia é-nos legado pelos estoicos. Sua teoria lógica, como parte de um todo sistemático, articulase com as outras partes de sua filosofia, particularmente com a sua teoria do conhecimento. Nesse aspecto, há um contraste notável entre a postura que se origina da tradição peripatética, que concebe a lógica de forma instrumental, uma verdadeira propedêutica filosófica, e a atitude estoica de integrar a lógica sistemicamente à sua filosofia. ${ }^{18}$ São-nos legadas por Diógenes Laércio as belas e inconfundíveis metáforas com as quais a lógica é descrita como parte constitutiva da filosofia:

Os estoicos comparam a filosofia a um ser vivo, onde os ossos e os nervos correspondem à lógica, as partes carnosas à ética e a alma à física. Ou então comparam-na a um ovo: a casca à lógica, a parte seguinte (a clara) à ética, e a parte central (a gema) à física. Ou a comparam ainda a um campo fértil: a cerca externa é a lógica, os frutos são a ética, e o solo ou as árvores são a física. Ou comparamna a uma cidade bem amuralhada e racionalmente administrada. E nenhuma parte é separada das outras, como dizem alguns estoicos, mas ao contrário todas estão estreitamente unidas entre si. (Vitae philosophorum, VII, 40)

Faz-se mister recordar que $\lambda$ оүıкฑं (logiké) designava, no mundo antigo, tudo aquilo que se situava no âmbito da razão ou do lógos. Assim, embora o termo "lógica" seja uma transliteração do termo grego, seus referentes atual e original não coincidem exatamente. Para os estoicos, a lógica abrangia a retórica e a dialética. O sentido contemporâneo de lógica seria, em parte, compatível, como antecipamos, com aquilo que os estoicos denominavam

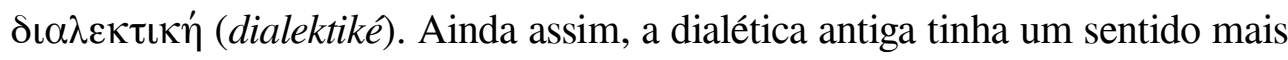
amplo que o da lógica atual; a dialética estoica, por exemplo, abrangia os significados e o som vocal. O âmbito dos significados subdividia-se no estudo das “representações”, como o som e a voz, e naquilo que subsistia a partir delas:

18 Vide também Blanché (2001, p. 108). 
os lekta..$^{19}$ Assim, os dizíveis, ao traduzirem as representações ( $\propto \alpha v \tau \alpha \sigma i \alpha$ ), colimam a dialética estoica à sua contraparte epistemológica. ${ }^{20}$

É oportuno ressaltar que a lógica estoica, primorosamente sistematizada por Crisipo de Soli, alcança, na Antinguidade, grande reputação, maior até que aquela então obtida pela lógica peripatética, ${ }^{21}$ donde se depreende que a visão segundo a qual a lógica constitui parte intrínseca da filosofia foi igualmente bem difundida. Uma passagem de Clemente de Alexandria, autor cristão do final do segundo e do princípio do terceiro século da era cristã, dá a dimensão desse prestígio. Ele afirma no Stromata (VII, 16, 323) que Crisipo é o mestre dentre os lógicos, Aristóteles é o mestre dentre os cientistas, Platão é o mestre dentre os filósofos e Homero o é dentre os poetas. A escola estoica mantinha grande vigor ainda no tempo de Marco Aurélio $(\dagger 180) .{ }^{22}$

É bem conhecido que a ética constituía o propósito máximo de toda reflexão filosófica no período helenístico. Nesse sentido, quanto ao estoicismo, salienta Barnes (1997, p. 10-11; nossa tradução): “A física e a lógica eram abordadas apenas na medida em que poderiam servir a um fim ético, e o objetivo e o propósito da filosofia era apresentar ao homem como melhor conduzir a sua vida”. Nesse contexto, contudo, a atitude quanto à lógica adotada por alguns autores como Marco Aurélio é claramente negativa. Todavia, segundo

\footnotetext{
${ }^{19}$ Diógenes Laércio e Sexto Empírico apresentam os $\lambda \varepsilon \kappa \tau \alpha$ como aquilo que subsiste após

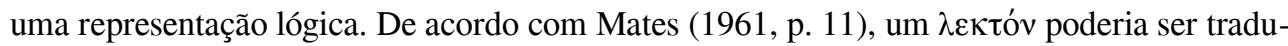
zido literalmente como "aquilo que é significado". Ildefonse (2007, p. 102-105) sugere que o termo " $\lambda \varepsilon \kappa \tau$ óv", apesar de seu complexo significado, corresponde ao sentido de uma frase completa, podendo ser traduzido por "dito". Desse modo, apenas um $\lambda \varepsilon \kappa \tau$ óv incompleto corresponderia ao sentido de um termo, de um predicado. Os lekta são, juntamente com o tempo, o lugar e o vazio, um dos quatro incorpóreos admitidos pelos estoicos. Ao contrário dos

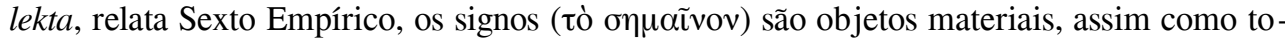
dos os demais objetos segundo a filosofia estoica; vide Mates (1961, p. 13).

${ }^{20}$ Cf. Ildefonse (2007, p. 100) e Barnes (1997, p. 8-9). Segundo Ildefonse (Id., 102), "o que garante a passagem do evidente da percepção ao não evidente e define o processo da ciência é a representação lógica (phantasia logiké) suscetível de composição e de transição (synthetikè kai metabatikè), e o logos que desenvolve essa representação”. Sobre esse ponto, vide Sexto Empírico, Adv. Math. VIII, 70 e Diógenes Laércio, VP, VII, 63. O último explica que a representação é o efeito sofrido na alma (pa thos en tèi psychèin), precisamente em sua parte diretora (hegemonikon), e é nessa porção que se produzem os impulsos e as representações, bem como a partir daí é emitida a linguagem; vide VP, VIII, 159.

${ }^{21}$ Sobre o declínio da lógica peripatética na Antiguidade tardia, vide Speca (2001, p. 3-6).

${ }^{22}$ Para uma análise e interpretação do papel da lógica estoica no estabelecimento de uma abordagem de cunho lógico relevante e paraconsistente na lógica grega antiga, vide Gomes \& D’Ottaviano (2017, p. 127-142).
} 
Barnes (1997, p. 4), a ideia de que a lógica foi completamente abandonada e relegada ao final do Antigo Stoá, após o II século a.C., parece equivocada.

O cenário, não obstante, é bem diverso desse. ${ }^{23}$ A propósito, explica Barnes, "os contemporâneos de Epicteto não eram moralistas cegos, ignorando os estudos lógicos que o Antigo Stoá tinha padronizado. Ao contrário, a filosofia - a filosofia estoica - tinha virtualmente se reduzido à lógica”. Esse parecer mostra como, no contexto da lógica estoica da era imperial, as coisas se passavam de modo muito diferente da opinião corrente sobre esse período, do que Barnes (1997, p. 37; nossa tradução) conclui: "Os filósofos eles mesmos pensam apenas em seus silogismos. Seus jovens estudantes eram escolados em técnica lógica e não poderiam encontrar melhor conversa à mesa de jantar que inferências hipotéticas e o argumento Mestre". ${ }^{24}$

As Diatribes de Epicteto mostram um autor voltado, em primeiro plano, à temática ética. Apesar dessa tendência marcante, sua obra contém numerosas alusões a assuntos que pertencem à lógica. Do começo ao fim dessa obra, a terminologia lógica pode ser encontrada. Ele menciona, por exemplo, os condicionais (

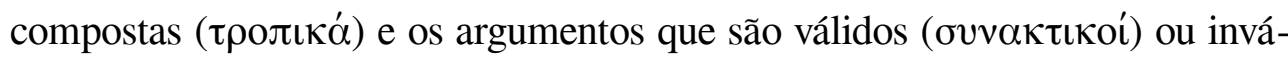

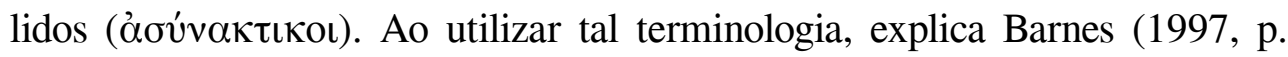
28), Epicteto o faz sem aviso e sem dar-lhe qualquer destaque especial, como alguém treinado que deixa o vocabulário lógico perpassar naturalmente seu discurso.

Epicteto lega-nos, em suas Diatribes, na forma de um argumento por redução ao absurdo logicamente clássica, uma das mais belas apologias à lógica de que se tem notícia. Formalmente falando, trata-se de uma peritropé semelhante àquela utilizada por Platão no Teeteto (171 B-C), mas que visa

\footnotetext{
${ }^{23}$ Barnes (1997, p. 37; nossa tradução): "Que a lógica excitou e atraiu era um lugar-comum. Assim, se consideramos o que Epicteto e seus companheiros realmente dizem e sugerem acerca da vida intelectual de seu tempo, vemos um retrato completamente diferente daquele pintado pela visão comum sobre o estoicismo imperial”.

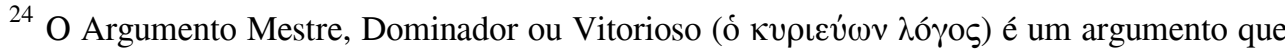
Diodoro Cronos propôs a fim de estabelecer sua própria definição de possibilidade. É de Epicteto a única versão completa que possuímos desse argumento; cf. Kneale \& Kneale (1991, p. 121, n. 3).
} 
demonstrar que o estudo da lógica é necessário. ${ }^{25}$ A passagem toda é a seguinte:

QUÃO NECESSÁRIA É A LÓGICA:

[1] Quando algum dos presentes disse:

- Persuade-me de que a lógica é útil.

- Queres, disse Epicteto, que te demonstre isso?

[2] - Sim!

- Portanto, é-me preciso selecionar um argumento demonstrativo?

Quando o outro concordou, <Epicteto disse >:

- E como saberás se eu te apresentar um sofisma?

[3] Quando o homem se calou, Epicteto disse:

- Vês como tu mesmo concordas que a lógica é necessária, já que sem ela não é possível saber se é necessária ou não. ${ }^{26}$

De acordo com Barnes, a expressão $\tau \alpha \tilde{v} \tau \alpha$ no original indica a lógica

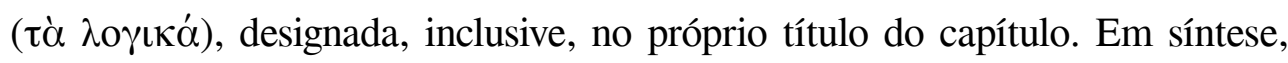
Epicteto argumenta que, para saber se é ou não necessário estudar lógica, estudar lógica necessário o é. O argumento de Epicteto pode ser assim reescrito:

(1) Se é necessário estudar lógica, então é necessário estudar lógica.

(2) Se não é necessário estudar lógica, então [ainda assim] é necessário estudar lógica.

(3) Portanto, é necessário estudar lógica. ${ }^{27}$

Tal esquema da inferência de Epicteto é bastante próximo ao argumento aristotélico acerca da inexorabilidade do filosofar preservado no Protréptico. Aqui, como lá - quando Aristóteles demonstra que, mesmo se alguém se negar a filosofar, filosofará de qualquer $\operatorname{modo}^{28}-$, Epicteto conclui que, ain-

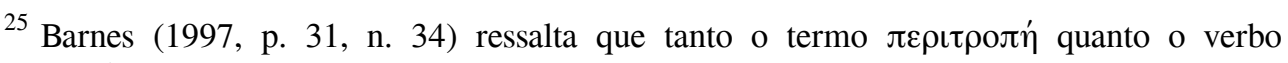
$\pi \varepsilon \rho \iota \tau \varepsilon^{\prime} \pi \varepsilon \iota v$ não são encontrados em Epicteto.

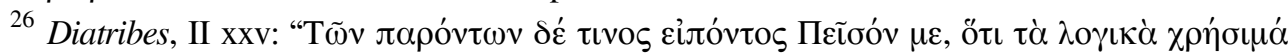

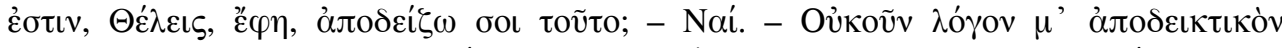

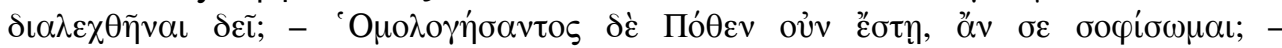

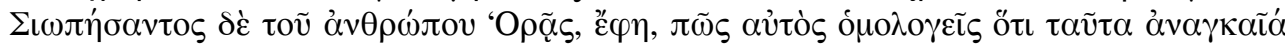

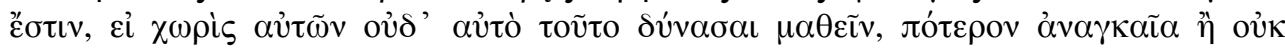

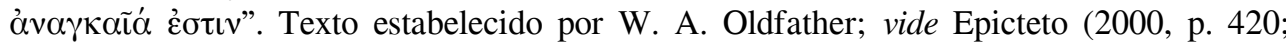
422). Tradução de Aldo Dinucci; vide Dinucci (2015, p. 195-196).

27 Salientamos, contudo, que o esquema de inferência de Epicteto expresso ao modo estoico assim se apresenta:

(1) Se o primeiro, então o primeiro.

(2) E, se não o primeiro, então o primeiro.

(3) Portanto, o primeiro.

28 Vide Fragmento 51 Rose $^{3}$ (Elias, Prolegomena Philosophiae 3.17 - 23). In: Aristóteles (1985, vol. 2, p. 2.416-2.417). Essa versão do argumento aristotélico pode assim ser formalizada:
}

$$
((A \rightarrow A) \wedge(\sim A \rightarrow A)) \rightarrow A .
$$


da que não se queira estudar lógica, ter-se-á que a estudar para distinguir sofismas de argumentos válidos, o que implica (para quem pretende propor argumentos) que estudar lógica sobrevém de qualquer maneira. $\mathrm{O}$ esquema de inferência subjacente ao argumento de Epicteto, análogo àquele utilizado por Aristóteles no Protréptico, é válido na lógica clássica e equivale à consequentia mirabilis. ${ }^{29}$ Aqui também se aplicariam, mutatis mutandis, as condições postuladas por Kneale para que argumentos assim construídos fossem válidos, ou seja, somente quando a proposição em questão fosse necessária..$^{30}$ Assim, uma vez que o estudo da lógica se mostra necessário, necessário é, do ponto de vista da apologia de Epicteto, estudar lógica. Portanto, abandonar o estudo da lógica equivale a renunciar ao filosofar.

Tendo analisado alguns elementos da abordagem peripatética e estoica à lógica, pode-se concluir que uma pretensa dicotomia entre lógica e filosofia não se pode abrigar no legado das grandes filosofias que inauguraram a tradição lógico-filosófica ocidental. Lógica e filosofia são disciplinas afins tanto na tradição peripatética quanto na estoica, sendo que, nesta última, a lógica é explicitamente admitida enquanto constituinte sistêmico da própria filosofia.

\section{Lógica e filosofia, uma falsa dicotomia}

Temos até aqui argumentado acerca do papel fundamental e fundante da lógica na codificação da atividade teórico-racional e na descrição das inferências tanto filosóficas quanto científicas. Em razão dos elementos já apresentados, aduz-se que as tradições peripatética e estoica valorizam a lógica, não obstante uma certa visão instrumental da disciplina pareça ter se descolado e reelaborado posteriormente na história da filosofia, a partir da concepção propedêutica de lógica, originalmente, de índole peripatética.

Semelhante visão instrumental da lógica como ferramenta, técnica ou arte é aprofundada no Renascimento e na Modernidade. Nesse estádio históri-

Vide também Bocheński (1966, p. 43-44).

${ }^{29}$ A consequentia mirabilis (ou lei de Clavius), em símbolos, assim se denota:

$(\sim A \rightarrow A) \rightarrow A$.

Vide discussão adicional em Gomes \& D'Ottaviano (2017, p. 82-84).

${ }^{30}$ Kneale (1966, p. 162-166). 
co, ao relegarem boa parte da tradição lógica anterior, os modernos introduzem seus próprios reparos à teoria lógica, em grande medida de caráter epistemológico, mas também, e inclusive, de índole psicologista. ${ }^{31}$ Essa é a perspectiva consagrada na La Logique, ou l'Art de penser de Port-Royal,,$^{32} \mathrm{o}$ mais emblemático dos textos de lógica da época. Nesse período, na medida em que variaram os interesses teóricos - com exceção feita a Leibniz e, em certa medida, a Kant -, diversos autores modernos passaram a ver a lógica como algo estranho e, por vezes, até avesso à própria filosofia. Tal visão ecoa ainda em nosso tempo, em que a filosofia se apresenta como um mosaico de diferentes escolas, problemas, programas, linguagens e métodos.

A falsa dicotomia está, desde então, constituída. ${ }^{33}$ É justamente por entender que a lógica é independente da filosofia que muitos autores e intérpretes declaram dela sua independência. Assim, a lógica passa a ser encarada como algo apartado e, por vezes, também dispensável ao exercício filosófico. Radicam á, ao lado de diferentes concepções acerca do fundamento do conhecimento para racionalistas e empiristas, as correlações que originam posturas de apreço ou desapreço à lógica.

Encontramos na história da filosofia algumas tentativas de solução para a presente "falsa dicotomia". Advém de Pedro Abelardo (1079-1142), célebre lógico, filósofo e teólogo do século XII, um lúcido argumento capaz de desfazer a falsa dicotomia entre lógica e filosofia. Com efeito, Abelardo desenvolve, no princípio da Logica ingredientibus, uma defesa de que a lógica é parte indissociável da atividade filosófica:

Para aqueles que dentre nós que se introduzem na Lógica, falemos previamente um pouco a respeito de sua característica própria, começando pelo gênero a que pertence, isto é, a Filosofia. Ora, Boécio não chama de Filosofia qualquer ciência, mas apenas a que se detém nas coisas mais elevadas; de fato, não chamamos de filósofos a quaisquer pessoas dotadas de conhecimento, mas apenas àquelas cu-

\footnotetext{
31 Vide Buickerood (1985) e Cassirer (1994).

32 Vide Arnauld \& Nicole (1964).

${ }^{33}$ Ressalve-se que há também na Antiguidade posições adversas quanto à lógica. Sexto Empírico, por exemplo, nunca a aprecia como fundamento viável ao conhecimento. O’Toole \& Jennings (2004, p. 484, nossa tradução) explicam que "como cético Sexto pretendia desacreditar as visões de todos os assim chamados 'filósofos dogmáticos'. Com respeito aos estoicos, isto teria envolvido, entre outras coisas, mostrar seu sistema lógico como inútil como meio de realizar inferências ou sustentar demonstrações".
} 
ja inteligência penetra as sutilezas. Boécio distingue três espécies de Filosofia, a saber: a especulativa, que se ocupa da natureza das coisas a ser investigada; a moral, que se ocupa da dignidade da vida a ser considerada; a racional, denominada Lógica pelos gregos, que se ocupa da ordem dos argumentos a serem compostos. (Logica "Ingredientibus", 1$)^{34}$

É claro que Pedro Abelardo introduz seus enunciados num contexto lógico-filosófico historicamente constituído, a logica vetus, na escolástica inicial. Isso não restringe o alcance de sua argumentação, pois, tal como ele, falamos de noções gerais e abrangentes de lógica e filosofia. Nesse contexto, o filósofo deixa claro que a lógica é uma espécie intrínseca à filosofia e que possui como propriedade fundamental a "ordem dos argumentos", o que remete ao modus operandi formal típico da disciplina. Esse traço nunca se perdeu, apesar de, em diferentes períodos de sua história, a lógica ter sido cultivada em benefício das prioridades típicas de cada conjuntura histórica. Pedro Abelardo, o Peripateticus Palatinus, não vê razões para qualquer desconexão entre lógica e filosofia. Tal dicotomia é afastada quando, na verdade, todos os saberes se beneficiam dos recursos dialéticos da lógica:

Isso porque, de um certo modo, as demais partes dela [da Lógica] se ocupam, na medida em que se servem de seus argumentos, para provar suas próprias questões. Assim, se se coloca uma questão pertinente à investigação da natureza ou da moral, os argumentos são tirados da Lógica. Contra esses, o próprio Boécio diz que nada impede que a Lógica seja tanto instrumento como parte de algo, assim como a mão o é em relação ao corpo humano. (Logica "Ingredientibus"; grifos nossos)

Pedro Abelardo divisa, assim, tanto a metalógica quanto a lógica aplicada, como facetas distintas da mesma parte da filosofia racional, todas voltadas a analisar filosoficamente as minúcias das questões teóricas e práticas. Além disso, ele introduz um argumento decisivo na polêmica que aqui analisamos, de que à lógica é indiferente se é instrumento ou constituinte da filosofia: há muitos exemplos dessa duplicidade que atestam a mútua pertinência entre as coisas comparadas. Portanto, da mesma forma que a mão é parte e instrumento do corpo humano, assim também a lógica é, simultaneamente,

${ }^{34}$ Tradução de Carlos A. R. do Nascimento; vide Pedro Abelardo (2005, p. 39-40). 
instrumento e parte da filosofia e de seus diferentes gêneros de análise e questões.

A fina percepção do autor quanto à natureza da análise metalógica antecipa perspectivas típicas do século XX e faz-se nítida no passo seguinte de sua argumentação, no qual a lógica não é menos lógica quando aplicada a si mesma.

\begin{abstract}
Além disso, a própria Lógica se apresenta muitas vezes como instrumento de si própria, visto que demonstra também uma questão a si pertinente com argumentos seus, como, por exemplo, a seguinte: o homem é uma espécie de animal. Contudo, nem por isso é menos Lógica, por ser instrumento da Lógica. Assim, também não é menos Filosofia por ser instrumento da Filosofia. O próprio Boécio a distingue das duas outras espécies de Filosofia pelo seu fim próprio que consiste em compor argumentações. Pois, embora o estudioso da natureza componha argumentos, não é o estudo da natureza que o institui para tal, mas apenas a Lógica. (Logica "Ingredientibus"; grifos nossos)
\end{abstract}

Pedro Abelardo entende que a lógica exerce papel regulativo da atividade racional, conformando todo e qualquer empreendimento epistêmico. Nesse sentido, ele não deixa de valorizar a lógica como o manancial do método, pois, apesar de sua natureza formal, essencial na composição dos argumentos, é a lógica que orienta o estudioso na descoberta e na formulação das leis da natureza. ${ }^{35}$

\title{
Considerações finais
}

De tudo quanto dissemos, concluímos que a "falsa dicotomia" entre lógica e filosofia não resiste a um exame atento da própria história da filosofia e da lógica, sendo que apenas forçosamente se pode operar essa separação.

Tal aposta, que minora ou despreza o papel da lógica na atividade filosófica, pode estar associada à ênfase em leituras modernistas da história da filosofia, que sobrevalorizam as questões e a abordagem dos modernos, período

\footnotetext{
35 Algumas leis lógicas, explica Pedro Abelardo, podem ser mais do que uma simples relação lógica, pois expressam uma lei da natureza (lex naturae); vide Martin (1987, p. 390). Desse modo, uma proposição maximal no contexto da teoria dos tópicos exprime, segundo Martin, "uma verdadeira restrição ontológica geral sobre a estrutura do mundo. Proposições maximais fornecem, como se o fossem, esquemas de acordo com os quais leis da natureza poderiam ser geradas".
} 
em que, além de ter estacionado seu percurso criativo, a lógica foi preterida mediante novos interesses teóricos. Há que ressaltar que a grande ênfase no estudo da filosofia moderna em cursos universitários de filosofia resulta em perda de perspectiva, semelhante àquela deformação, tão flagrante quanto naturalizada, que confunde as proporções do globo terrestre com a representação do planisfério de Mercator, com os continentes e os oceanos aparecendo distorcidos. De modo análogo, em filosofia, determinadas visões fazem alguns campos de estudo parecerem maiores ou menores, ou mais centrais ou periféricos do que realmente o são.

Enfim, manifestações de desapreço à lógica nos dias atuais só se podem explicar pela falta de conhecimento do que seja o seu papel na própria história da filosofia, bem como do que seja a lógica e de como suas diferentes formas historicamente constituídas (greco-escolástica, tradicional e simbólicomatemática) exprimem a evolução de uma mesma disciplina tão importante para a crítica do conhecimento como para a própria filosofia.

\section{Referências}

ARISTÓTELES. The complete works of Aristotle: the revised Oxford translation. Edited by J. Barnes. Princeton: Princeton University Press, 1985. 2 vols. (Bollingen series, LXXI)

. Metafísica - Livros IV e VI. Tradução, introdução e notas de L. Angioni. Campinas: Instituto de Filosofia e Ciências Humanas-Unicamp, 2001. (Textos Didáticos, 45)

ARNAULD, A. \& NICOLE, P. La logique ou L'Art de Penser. Édition critique présentée par Pierre Clair et François Girbal. Paris: Presses Universitaires de France, 1964.

AUSTIN, S. Parmenides: being, bounds, and logic. New Haven, London: Yale University Press, 1986.

BARNES, J. Logic \& the imperial stoa. Leiden, New York, Köln: Brill, 1997.

The Presocratic Philosophers. London, New York: Routledge, 2000. (The arguments of the philosophers)

BLANCHÉ, R. História da lógica. Atualizado por J. Dubucs. Trad. A. P. Ribeiro e P. E. Duarte. Lisboa: Edições 70, 2001. 
BOCHEŃSKI, I. M. Ancient Formal Logic. Amsterdam: North-Holland, 1951.

. Historia de la Lógica Formal. Tradução de M. Bravo Lozano. Madrid: Gredos, 1966. (Biblioteca Hispánica de Filosofía)

BUICKEROOD, J. G. "The Natural History of the Understanding: Locke and the Rise of Facultative Logic in the Eighteenth Century". History and Philosophy of Logic, 6, 1985, p. 157-190.

CASSIRER, E. A filosofia do Iluminismo. Tradução de Álvaro Cabral. $2^{\mathrm{a}}$ ed. Campinas: Editora da Unicamp, 1994.

CORDERO, N. L. "Zenón de Elea”. In: GARCIA GUAL, C. (ed.). Los filósofos presocráticos. Madrid: Gredos, 1994, vol. II, p. 7-63. (Biblioteca Clásica Gredos, 24)

CORREIA, M. La logica de Aristoteles: lecciones sobre el origen del pensamiento lógico en la antigüedad. Santiago: Ediciones Universidad Católica de Chile, 2002.

DA COSTA, N. C. A. Ensaio sobre os fundamentos da lógica. São Paulo: Edusp-Hucitec, 1980.

DINUCCI, A. "Epicteto: Diatribes I.7 e II.25 - Relação entre a lógica e as ações convenientes". Revista Clássica, vol. 29, n. 1, 2015, p. 193-203.

DIÓGENES LAÉRCIO. Vidas e doutrinas dos filósofos ilustres. Tradução do grego, introdução e notas de M. da G. Kury. 2aㅗ ed. Brasília: Editora UnB, 2008.

ENRIQUES, F. Para la historia de la logica. Buenos Aires: Espasa-Calpe, 1948. (Historia y Filosofia de la Ciencia)

FERRATER MORA, J. Dicionário de Filosofia. São Paulo: Loyola, 2000, 4 tomos.

GOMES, E. L. \& D’OTTAVIANO, I. M. L. Para além das Colunas de Hércules, uma história da paraconsistência: de Heráclito a Newton da Costa. Campinas: Editora da Unicamp, 2017.

GUTHRIE, W. K. C. A history of Greek philosophy. Cambridge: Cambridge University Press, 1962. (Vol. 1: The earlier presocratics and the phytagoreans)

ILDEFONSE, F. Os Estóicos I. Tradução de M. Pinheiro. São Paulo: Estação Liberdade, 2007. 
KIRK, G. S., RAVEN, J. E. \& SCHOFIELD, M. Os filósofos pré-socráticos:

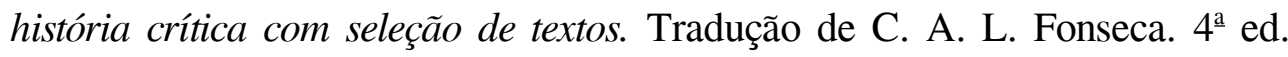
Lisboa: Calouste Gulbenkian, 1994.

KNEALE, W. "Aristotle and the Consequentia Mirabilis". The Journal of Hellenic Studies, vol. 77, n. 1, 1966, p. 162-166.

KNEALE, W. \& KNEALE, M. O desenvolvimento da lógica. Tradução de M. S. Lourenço. $3^{\mathrm{a}}$ ed. Lisboa: Calouste Gulbenkian, 1991.

LAUDAN, L. "Teorias do método científico de Platão a Mach: resenha bibliográfica”. Cadernos de História e Filosofia da Ciência, vol. 10, n. 2, 2000, p. $1-140$.

MARTIN, C. J. "Embarrassing arguments and surprising conclusions in the development of theories of the conditional in the twelfth century". In: JOLIVET, J. \& DE LIBERA, A. (eds.). Gilbert de Poitiers et ses contemporains. Naples: Bibliopolis, 1987, p. 377-400.

MATES, B. Stoic Logic. 2aㅡ. ed. Berkeley, Los Angeles: University of California Press, 1961.

O'TOOLE, R. O. \& JENNINGS, R. E. "The Megarians and the Stoics". In: GABBAY, D. M. \& WOODS, J. (eds.). Handbook of the history of logic; Greek, Indian and Arabic Logic. Amsterdam: Elsevier, 2004, p. 397-522. (Handbook of the History of Logic, 1)

PEDRO ABELARDO. Lógica para principiantes. Tradução do original latino por C. A. R. do Nascimento. 2 ${ }^{\mathrm{a}}$ ed. São Paulo: Editora Unesp, 2005.

SANTOS, C. A. dos. O Górgias retórico e o Górgias de Platão. Dissertação (Mestrado em Filosofia). São Paulo: Pontifícia Universidade Católica de São Paulo, 2008.

SPECA, A. Hypothetical syllogistic and Stoic logic. Leiden, Boston, Köln: Brill, 2001. (Philosophia Antiqua, 87) 